\title{
Isolated Renal Sarcoidosis Presenting with Granulomatous Interstitial Nephritis: A Case Report and Review of the Literature
}

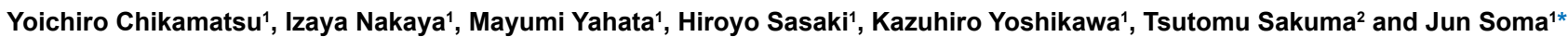

${ }^{1}$ Departments of Nephrology, Iwate Prefectural Central Hospital, Morioka, Japan

${ }^{2}$ Departments of Pathology, Iwate Prefectural Central Hospital, Morioka, Japan

\begin{abstract}
Background: Sarcoidosis is a multi-system disorder characterized by noncaseating epitheloid granuloma in multiple organs. However, granulomatous interstitial nephritis in the absence of extrarenal renal lesions is very rare.

Case presentation: A 64-year-old male presented with a weight loss of $10 \mathrm{~kg}$ and an increase in serum creatinine from 1.1 to $4.8 \mathrm{mg} / \mathrm{dl}$ over a 1-year period. At admission, no proteinuria or hematuria was found, although serum creatinine was $5.1 \mathrm{mg} / \mathrm{dl}$ and was associated with slight increases in serum angiotensin converting enzyme and calcium levels. Renal biopsy revealed granulomatous interstitial nephritis with noncaseating epitheloid cells. The patient was diagnosed with sarcoidosis, although no extrarenal sarcoid lesion was found. Oral prednisolone was effective, with normalization of serum creatinine levels 2 weeks later. A review of the literature showed that isolated granulomatous renal sarcoidsosis preferentially affected elderly males, and their serum angiotensin converting enzyme levels were normal or mildly increased in many cases.
\end{abstract}

Conclusions: This paper describes a rare case of isolated renal sarcoidosis with acute granulomatous interstitial nephritis. This case and a relevant review of the literature demonstrate that sarcoid granulomatous interstitial nephritis should be considered as one of differential diagnoses in elderly male patients with suspected tubulointerstitial nephritis irrespective of angiotensin converting enzyme levels.

Keywords: Renal limited sarcoidosis; Granulomatous interstitial nephritis; Angiotensin converting enzyme; Acute kidney injury

\section{Introduction}

Sarcoidosis is a multisystem, granulomatous disease of unknown cause characterized by the formation of noncaseating epitheloid granuloma. It has been postulated that the disease is caused by exposure of a genetically susceptible subject to an environmental agent [1]. Recently, tumor necrosis factor (TNF)- $\alpha$ has also been investigated in detail, and it reportedly plays a central role in granuloma formation [1]. Although sarcoidosis affects all generations, it typically develops in individuals aged below 50 years, with the incidence peaking between 20 and 39 years [2]. Laboratory presentation often includes elevated serum calcium, angiotensin converting enzyme (ACE), and lysozyme levels [3-5]. Although granulomatous lesions preferentially involve the lung and intrathoracic lymph nodes, they may also involve any organ such as the skin, eyes, liver, and kidney [1,4,5]. Renal injuries in sarcoidosis are primarily caused by hypercalcemia and/or hypercalciuria, which lead to nephrocalcinosis, nephrolithiasis, and renal dysfunction [6]. It has been reported that granulomatous interstitial nephritis (GIN) associated with sarcoidosis is found in $7 \%-27 \%$ autopsy cases of systemic sarcoidosis, although many of these cases exhibit clinically silent renal symptoms $[7,8]$. The incidence of clinically relevant renal GIN is therefore very low, and it is difficult to identify accurately [9]. We recently encountered a patient with acute kidney injury due to sarcoid GIN who had no evidence of extrarenal sarcoid in any other organ. To the best of our knowledge, 29 cases of isolated renal GIN have been reported till date. Here we describe a rare case and present a review of the relevant literature.

\section{Case Report}

A 64-year-old male who was undergoing treatment for hypertension and hyperuricemia was referred to our hospital with a rapid increase in serum creatinine level from $1.1 \mathrm{mg} / \mathrm{dL}$ to $4.8 \mathrm{mg} / \mathrm{dl}$ and a weight loss of $10 \mathrm{~kg}$ over a 1 -year period.
On admission, his blood pressure was $118 / 76 \mathrm{~mm} \mathrm{Hg}$, body temperature was $36.7^{\circ} \mathrm{C}$, height was $169.9 \mathrm{~cm}$, and weight was 57.9 kg. Physical examination showed no abnormalities in the heart, lungs, and abdomen. His lymph nodes were not palpable. Urinalysis revealed neither proteinuria nor hematuria, although urinary $\beta 2$ microglobulin levels were markedly increased to $8430 \mu \mathrm{g} / \mathrm{l}$ (normal, $<230 \mu \mathrm{g} / \mathrm{l})$. Hematological findings were as follows: erythrocyte count,

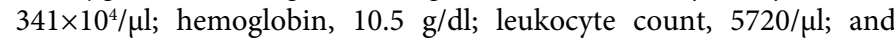
platelet count, $20.3 \times 10^{4} / \mu \mathrm{l}$. Blood chemistry revealed the following: blood urea nitrogen, $63.1 \mathrm{mg} / \mathrm{dl}$; creatinine, $4.84 \mathrm{mg} / \mathrm{dl}$; uric acid, $7.1 \mathrm{mg} / \mathrm{dl}$; potassium, $134 \mathrm{mEq} / \mathrm{dl}$; sodium, $4.7 \mathrm{mEq} / \mathrm{dl}$; chloride, 102 $\mathrm{mEq} / \mathrm{dl}$; calcium, $11.8 \mathrm{mg} / \mathrm{dl}$; phosphorous, $4.4 \mathrm{mg} / \mathrm{dl}$; total protein, $7.5 \mathrm{~g} / \mathrm{dl}$; albumin, $4.3 \mathrm{~g} / \mathrm{dl}$; aspartate aminotransferase, $10 \mathrm{IU} / \mathrm{l} ;$ alanine aminotransferase, $11 \mathrm{IU} / \mathrm{l}$; and C-reactive protein, $0.02 \mathrm{mg} /$ dl. Serological studies revealed the following: serum immunoglobulin (Ig) G, $1789 \mathrm{mg} / \mathrm{dl}$ (normal, 870-1700 mg/dl); serum IgA, $420 \mathrm{mg} /$ dl (normal, 110-410 mg/dl); serum IgM, $84 \mathrm{mg} / \mathrm{dl}$ (normal, 34-220 $\mathrm{mg} / \mathrm{dl}$ ); complement component 3, $88 \mathrm{mg} / \mathrm{dl}$ (normal, 63-134 mg/ $\mathrm{dl}$ ); C4, $32 \mathrm{mg} / \mathrm{dL}$ (normal, 13-36 mg/dl); hemolytic complement activity, $46.0 \mathrm{U} / \mathrm{ml}$ (normal, 30-50 U/ml); anti-nuclear antibody, $\times 80$ (speckled); anti-double stranded DNA antibody, $10 \mathrm{IU} / \mathrm{ml}$ (normal, $<12 \mathrm{IU} / \mathrm{ml}$ ). Anti-SS-A and anti-SS-B antibodies, anti-Sm antibody, and myeloperoxidase- and proteinase 3-anti-neutrophil cytoplasmic

*Corresponding author: Jun Soma, Department of Nephrology, Iwate Prefectura Central Hospital, 1-4-1 Ueda, Morioka, Iwate 020-0066, Japan, Tel: +81-19-653 1151; Fax: +81-19-653-8919; E-mail: sjun@chuo-hp.jp

Received February 05, 2014; Accepted March 22, 2014; Published March 27 2014

Citation: Chikamatsu Y, Nakaya I, Yahata M, Sasaki H, Yoshikawa K, et al. (2014) Isolated Renal Sarcoidosis Presenting with Granulomatous Interstitial Nephritis: A Case Report and Review of the Literature. J Nephrol Therapeutic S1: 008 doi:10.4172/2161-0959.S1-008

Copyright: (c) 2014 Chikamatsu Y, et al. This is an open-access article distributed under the terms of the Creative Commons Attribution License, which permits unrestricted use, distribution, and reproduction in any medium, provided the original author and source are credited. 
antibodies were all negative. Computed tomography from the chest to the pelvis showed normal-sized kidneys, no abnormalities of the lung field or hilum, and no lymphadenopathies. Ophthalmological and dermatological examinations showed no findings suggestive of uveitis, scleritis, or cutaneous sarcoidosis. An electron cardiogram appeared normal, while gallium scintigraphy showed no abnormal uptake.

Renal biopsy was performed on the fourth day of admission. The biopsy specimen contained 17 glomeruli on light microscopy, none of which were globally sclerotic. Approximately half the glomeruli were rather collaptic, with the remainder showing no mesangial proliferation, capillary wall abnormalities, or crescent formation (Figure 1a). Numerous granulomas of various sizes were diffusely distributed throughout the interstitium (Figure 1b). These granulomas were composed of noncaseating epitheloid and multinucleated giant cells and were surrounded by a marked infiltration of mononuclear cells (Figure 1c). Immunofluorescence studies and Ziehl-Neelsen staining for acid-fast bacilli were both negative.

Following the renal biopsy, serum ACE and lysozyme levels increased to $28.0 \mathrm{U} / \mathrm{l}$ (normal, 6-21 U/l) and $53.5 \mu \mathrm{g} / \mathrm{ml}$ (normal, 3-10.6 $\mu \mathrm{g} / \mathrm{ml}$ ), respectively. On the basis of the above-mentioned findings, the patient was diagnosed with isolated renal sarcoid GIN; $30 \mathrm{mg} /$ day of oral prednisolone was subsequently initiated. Two weeks later, serum creatinine and calcium levels decreased to $2.5 \mathrm{mg} / \mathrm{dl}$ and $8.0 \mathrm{mg} / \mathrm{dl}$, respectively. At the final follow-up visit a year later, the prednisolone dose was tapered to $6 \mathrm{mg} /$ day, and his laboratory data revealed a serum creatinine level of $2.0 \mathrm{mg} / \mathrm{dl}$, a serum calcium level of $9.2 \mathrm{mg} / \mathrm{dl}$, and a urinary $\beta 2$-microglobulin level of $2140 \mu \mathrm{g} / \mathrm{l}$.

\section{Discussion}

GIN is a rare histological diagnosis found in $0.5 \%-0.9 \%$ of native renal biopsies [10,11]. GIN is reportedly associated with infections, medications, sarcoidosis, tubulointerstitial nephritis with uveitis syndrome, granulomatosis with polyangiitis, oxalosis, and gout, and it is also observed in an idiopathic form [12]. In the present case, Ziehl-Neelsen staining was negative, and uveitis, oxaluria, and antineutrophil cytoplasmic antibodies were not observed. Neither antimicrobial agents nor nonsteroidal anti-inflammatory drugs, which are well-known causes of GIN, had been administered. Our patient also fulfilled the diagnostic criteria for sarcoidosis [13] as follows: 1) presence of noncaseating epitheloid granulomas, 2) elevation of serum ACE levels, and 3) elevation of serum calcium levels.

Sarcoidosis is a chronic, multisystem, inflammatory disorder of unknown origin, characterized by the formation of noncaseating epitheloid granulomas in the involved organs. The disease most commonly involves the lungs and intrathoracic lymph nodes, but any organ such as the skin, eyes, liver, and kidney may be affected $[1,14,15]$. Clinically relevant renal injury has been reported to occur in only a small percentage of patients with sarcoidosis, with the majority of renal injuries being caused by hypercalcemia and/or hypercalciuria, which lead to renal stone disease and nephrocalcinosis [16]. Hypercalciuria and hypercalcemia have been reported to occur in $40 \%$ and $11 \%$ patients with sarcoidosis [1]. The incidence of GIN in patients with sarcoidosis is uncertain. Although GIN is a widely- and well-known manifestation of sarcoidosis, clinically apparent sarcoid GIN is generally thought to be very rare [17]. On the other hand, autopsy studies identified sarcoid GIN in many patients with a clinically silent condition [17-19].
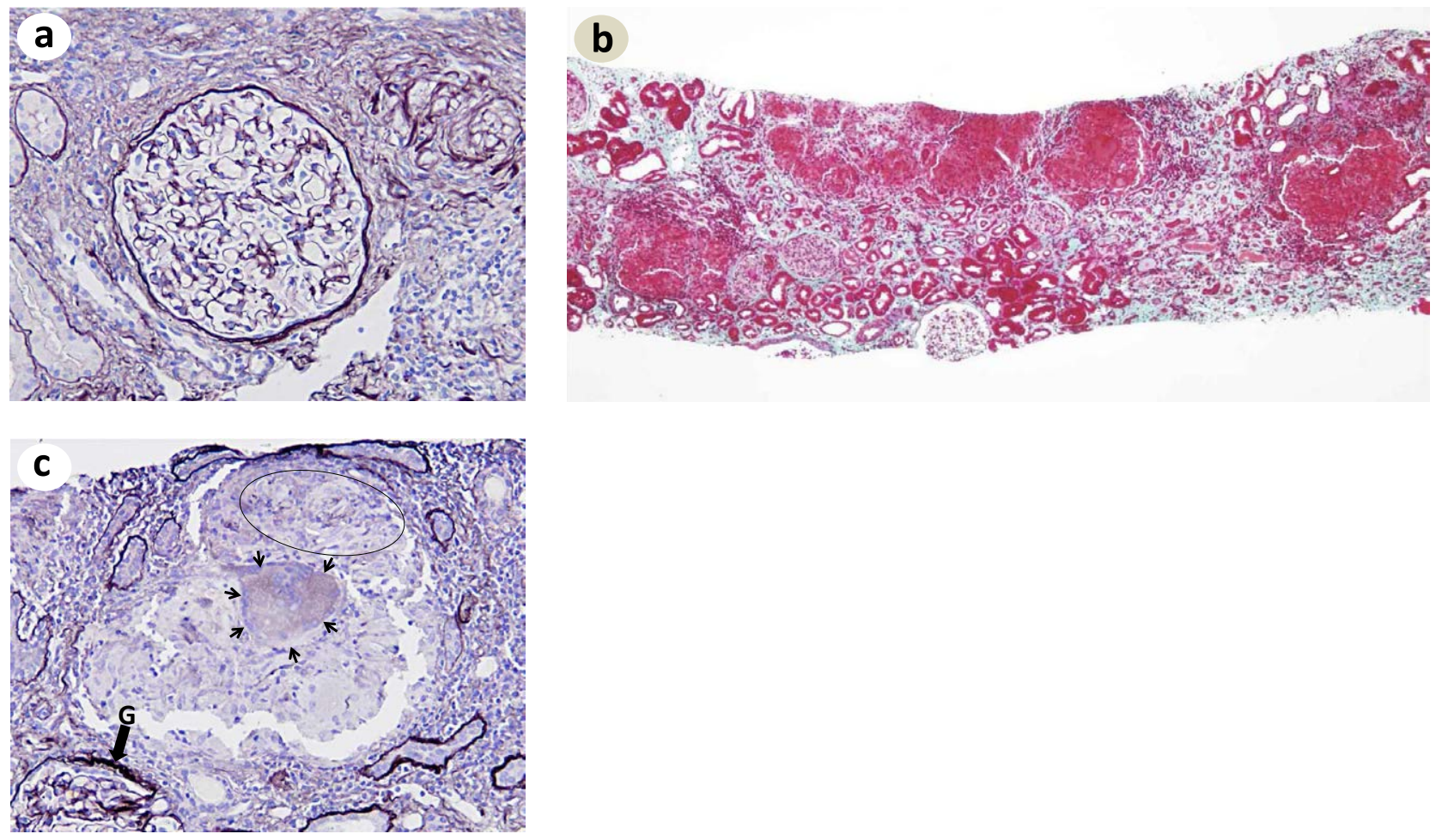

Figure 1: Light microscopic findings. (a) Neither proliferative changes nor glomerular capillary wall abnormalities are observed. Mononuclear cell infiltration and periglomerular fibrosis are seen around the glomerulus. (b) Many granulomas, which are positive for fuchsine and varied in sizes, are diffusely seen in the interstitum. (c) Note that the giant granuloma is composed of non-caseating epitheloid (oval) and multinucleated giant cells (small arrows). Marked mononuclear cell infiltration is also observed around the granuloma. G: glomerulus. (a) and (c) Periodic acid-methenamine-silver stain, and (b) Elastica-Goldner stain. Original magnification: (a) $\times 200$; (b) $\times 40$; and (c) $\times 100$. 
The present patient was diagnosed with isolated renal sarcoid GIN on the basis of no specific findings on computed tomography from the chest to the pelvis, no abnormal uptake on gallium scintigraphy, and an absence of disease in ophthalmological and dermatological examinations. Isolated renal sarcoid GIN is an extremely rare entity, and, to the best of our knowledge, only 29 cases have been reported in the literature published till date. Table 1 shows the characteristics of our patient and the 29 previously reported patients with isolated renal sarcoid GIN. The male to female ratio was 19:12 and the age range was 13-81 years. Seven patients were younger than 40 years, while 12 were older than 60 years. In contrast, sarcoidosis has been reported to affect females and young adults more frequently, with the incidence peaking between 20 and 39 years of age [2,20,21]. While these differences in age and male to female ratio characterize isolated granulomatous renal sarcoidosis, the precise cause for this variability remains uncertain. The mean serum creatinine level in 24 patients was $4.7 \pm 2.8 \mathrm{mg} / \mathrm{dl}$, and all patients exhibited a rapid increase in serum creatinine levels. Hemodialysis on admission was necessary in three patients. Proteinuria was minimal or negative in all but six patients, who exhibited levels of 1 to $3.6 \mathrm{~g} /$ day [22,23]. Hypercalcemia was observed in 5 of 28 patients $(17.9 \%)$, an incidence equivalent to that reported previously (10\%$20 \%)$ for sarcoidosis [24,25]. Hypercalcemia in sarcoidosis has been reported to associate with elevations of 1,25 -vitamin $\mathrm{D} 3$ produced by macrophage of sarcoid granuloma [1]. Unfortunately, 1, 25-vitamin
D3 was not measured in the present case. All patients were treated with prednisolone. The initial dose varied for each patient, although it was approximately $0.5-1 \mathrm{mg} / \mathrm{kg} /$ day. More recently diagnosed patients were treated with prednisolone combined with infliximab, mycophenolate mofetil, and azathioprine [24, 26-29]. These drugs were added so that the dose of prednisolone could be tapered or its efficacy could be improved. Among these drugs, infliximab, a TNF- $\alpha$ antibody, appears to be the most effective agent against sarcoidosis because TNF- $\alpha$ plays a critical role in the recruitment of $\mathrm{T}$ cells and formation of granulomas [1]. All patients except two (cases 16 and 18), who subsequently became hemodialysis-dependent, responded well to steroid therapy and showed a good prognosis. The three patients who underwent urgent hemodialysis on admission were able to discontinue this therapy $[30,31]$.

Interestingly, serum ACE levels were elevated in only 10 of 25 patients, with the degree of elevation in case 25 and our patient being very mild at $22.6 \mathrm{U} / 1$ (normal, 8.3-21.4 U/l) and $28.0 \mathrm{U} / 1$ (normal, 6-21 U/l), respectively. ACE is generally produced by pulmonary endothelial cells, but it is also produced by epitheloid cells under pathological conditions [32]. Measurement of serum ACE levels is valuable in the diagnosis of sarcoidosis and follow-up of disease activity [33], and it reportedly increases in $68 \%-86 \%$ patients with untreated sarcoidosis $[1,34,35]$. In comparison, the incidence of increased serum

\begin{tabular}{|c|c|c|c|c|c|c|c|}
\hline Case (reference) & Age/Gender & $\mathrm{Cr}(\mathrm{mg} / \mathrm{dl})[\mathrm{Ccr}(\mathrm{mL} / \mathrm{min})]$ & UP (g/day) [dipstick] & Calcium & ACE & Therapy & Final follow-up \\
\hline 1. [14] & $44 / F$ & 7.1 & 0 & normal & NA & PSL $60 / 0 \mathrm{mg}$ & $\mathrm{Cr} 1.3$ at $8 \mathrm{mo}$ \\
\hline 2. [15] & $48 / \mathrm{M}$ & 8.0 & {$[+]$} & normal & normal & PSL $60 \mathrm{mg}$ & $\mathrm{Cr} 4.0$ at $1.5 \mathrm{mo}$ \\
\hline 3. [16] & $66 / F$ & 4.3 & 1.2 & NA & NA & PSL $20 \mathrm{mg}$ & $\mathrm{Cr} 1.9$ at $15 \mathrm{mo}$ \\
\hline 4. [17] & $57 / F$ & 4.95 & 0.5 & normal & high & PSL $1 \mathrm{mg} / \mathrm{kg}$ & $\mathrm{Cr} 2.3$ at $89 \mathrm{mo}$ \\
\hline 5. [18] & $26 / \mathrm{M}$ & 5.3 & 0.36 & NA & NA & PSL 30mg & $\mathrm{Cr} 3.0$ at $14 \mathrm{mo}$ \\
\hline 6. [19] & $48 / F$ & 1.9 & 1.0 & normal & high & PSL $60 \mathrm{mg}$ & $\mathrm{Cr} 1.0$ at one mo \\
\hline 7. [20] & $14 / F$ & 5.13 & 0.4 & normal & NA & PSL $40 \mathrm{mg}$ & $\mathrm{CCr}$ at $3 \mathrm{mo}$ \\
\hline 8. [11] & $\mathrm{F}$ & [5] & NA & normal & & $\mathrm{HD}+$ & Ccr 18 at $48 \mathrm{mo}$ \\
\hline 9. [11] & M & [2] & NA & normal & & $\mathrm{HD}+$ & Ccr 40 at $11 \mathrm{mo}$ \\
\hline 10. [11] & $48 \sim 71 \mathrm{~F}$ & [6] & NA & normal & high in one & PSL $0.5-1 \mathrm{mg} / \mathrm{kg}$ & Ccr 20 at $12 \mathrm{mo}$ \\
\hline 11. [11] & M & [19] & NA & normal & & & Ccr 27 at $73 \mathrm{mo}$ \\
\hline 12. [11] & M & [20] & NA & normal & & & Ccr 20 at $17 \mathrm{mo}$ \\
\hline 13. [21] & $71 / \mathrm{F}$ & 6.0 & NA & high & high & $\mathrm{PSL} 1 \mathrm{mg} / \mathrm{kg}$ & $\mathrm{Cr} 2.1$ at $6 \mathrm{mo}$ \\
\hline 14. [22] & $35 / \mathrm{M}$ & 4.5 & $<0.5$ & normal & normal & PSL $60 \mathrm{mg}$ & $\mathrm{HD}$ at $15 \mathrm{mo}$ \\
\hline 15. [22] & $70 / \mathrm{M}$ & $4 . .0$ & 0.8 & high & high & PSL $30 \mathrm{mg}$ & Ccr 21 at $9 \mathrm{mo}$ \\
\hline 16. [22] & $69 / F$ & 3.4 & $<0.2$ & normal & normal & PSL $30 \mathrm{mg}$ & $\mathrm{HD}$ at $3 \mathrm{mo}$ \\
\hline 17. [22] & $64 / F$ & 3.4 & 0.4 & normal & normal & PSL $40 \mathrm{mg}$ & Ccr 55 at $48 \mathrm{mo}$ \\
\hline 18. [22] & $69 / \mathrm{M}$ & $5 . .6$ & 0.2 & normal & high & PSL $40 \mathrm{mg}$ & Ccr 29 at $3 \mathrm{mo}$ \\
\hline 19. [22] & $70 / \mathrm{M}$ & 14.2 & 0.9 & NA & normal & $\mathrm{HD}+\mathrm{PSL} 40 \mathrm{mg}^{*}$ & Ccr 22 at $56 \mathrm{mo}$ \\
\hline 20. [22] & $72 / \mathrm{M}$ & 4.5 & 0 & normal & high & PSL $20 \mathrm{mg}$ & Ccr 31 at $7 \mathrm{mo}$ \\
\hline 21. [23] & $41 / F$ & 2.1 & 3.6 & normal & normal & PSL $60 \mathrm{mg}$ & $\mathrm{Cr} 1.43$ at $17 \mathrm{mo}$ \\
\hline 22. [24] & $80 / \mathrm{M}$ & 7.1 & 0.37 & normal & low & $P S L 60 \mathrm{mg}+\mathrm{AZ}$ & $\mathrm{Cr} 3.5$ at $8 \mathrm{mo}$ \\
\hline 23. [25] & $62 / \mathrm{M}$ & 2.42 & 1.1 & high & high & PSL $20 \mathrm{mg}$ & Cr 1.5at $4 \mathrm{mo}$ \\
\hline 24. [26] & $13 / \mathrm{M}$ & 2.4 & 1.2 & normal & normal & $\mathrm{PSL} 1 \mathrm{mg} / \mathrm{kg}^{*}+\mathrm{IFX}$ & $\mathrm{Cr} 1.6$ at $10 \mathrm{mo}$ \\
\hline 25. [27] & $15 / \mathrm{M}$ & 7.2 & + & normal & normal & PSL 40 mg* + MMF & $\mathrm{Cr} 1.1$ at $21 \mathrm{mo}$ \\
\hline 26. [28] & $57 / \mathrm{M}$ & 2.9 & 1.4 & normal & high & PSL $60 \mathrm{mg}^{*}+\mathrm{IFX}$ & $\mathrm{Cr} 1.8$ at $17 \mathrm{mo}$ \\
\hline 27. [39] & $16 / \mathrm{M}$ & 1.34 & 0.46 & normal & normal & $\mathrm{PSL}^{*}+\mathrm{AZ}, \mathrm{MMF}$ & $\mathrm{Cr} 1.06$ at one mo \\
\hline 28. [30] & $37 / \mathrm{M}$ & 5.42 & 0 & high & high & PSL $40 \mathrm{mg}$ & Cr 0.97 at one mo \\
\hline 29. [31] & $30 / \mathrm{M}$ & 2.2 & 0 & high & normal & PSL $1 \mathrm{mg} / \mathrm{kg}$ & $\mathrm{Cr} 1.3$ at $6 \mathrm{mo}$ \\
\hline Current case & $64 / \mathrm{M}$ & 4.84 & $<0.1$ & high & high & PSL $30 \mathrm{mg}$ & $\mathrm{Cr} 0.96$ at $52 \mathrm{mo}$ \\
\hline
\end{tabular}

Ccr, creatinine clearance; $\mathrm{Cr}$, creatinine; UP, urinary protein; ACE, angiotensin converting enzyme; PSL, prednisolone; IFX, infliximab; MMF, mycophenolate mofetil; AZ, azathioprine; HD, hemodialysis; NA, not available; $60 / 0 \mathrm{mg}, 60 \mathrm{mg}$ every other day.

*Following methylprednisolone pulse therapy. The dose of prednisolone indicates that at initial therapy.

Table 1: Reported cases of isolated renal sarcoidosis showing acute granulomatous interstitial nephritis. 
Citation: Chikamatsu Y, Nakaya I, Yahata M, Sasaki H, Yoshikawa K, et al. (2014) Isolated Renal Sarcoidosis Presenting with Granulomatous Interstitial Nephritis: A Case Report and Review of the Literature. J Nephrol Therapeutic S1: 008 doi:10.4172/2161-0959.S1-008

Page 4 of 4

AGE levels in patients with isolated renal sarcoid GIN was low at $42 \%(11 / 26)$. While the reason for this difference remains unknown, we speculated that serum ACE levels may depend, at least in part, on the number of ACE-producing epitheloid cells. The number of ACEproducing epitheloid cells in renal sarcoidosis may be lesser than that in sarcoidosis involving multiple organs. In particular, pulmonary involvement is a rich source of ACE [23]. Therefore, it is possible that serum ACE level may not be a dependable parameter for diagnosing or evaluating disease activity during follow-up periods in patients with isolated renal sarcoid GIN.

\section{Conclusions}

We reported a rare case of isolated renal sarcoid GIN. Unlike sarcoidosis involving multiple organs, this disease may preferentially affect elderly males, and the rate of serum ACE positivity in this condition may be lower than that in systemic sarcoidosis. Therefore, it is important to consider the possibility of isolated renal sarcoid GIN when examining elderly male patients with suspected tubulointerstitial nephritis, even though the patient exhibits normal serum ACE levels.

\section{Acknowledgements}

The authors thank Shuichi Futatsumori for his excellent technical assistance. This work was presented at the 42nd Eastern Regional Meeting of the Japanese Society of Nephrology, October 13-14, 2012, Niigata, Japan.

\section{References}

1. lannuzzi MC, Rybicki BA, Teirstein AS (2007) Sarcoidosis. N Engl J Med 357 2153-2165.

2. Rybicki BA, Major M, Popovich J Jr, Maliarik MJ, lannuzzi MC (1997) Racia differences in sarcoidosis incidence: a 5-year study in a health maintenance organization. Am J Epidemiol 145: 234-241.

3. Turton CW, Grundy E, Firth G, Mitchell D, Rigden BG, et al. (1979) Value of measuring serum angiotensin I converting enzyme and serum lysozyme in the management of sarcoidosis. Thorax 34: 57-62.

4. Mayock RL, Bertrand P, Morrison CE, Scott JH (1963) Manifestations of sarcoidosis. Analysis of 145 patients, with a review of nine series selected from the literature. Am J Med 35: 67-89.

5. James DG (1984) Sarcoidosis. Postgrad Med J 60: 234-241.

6. Casella FJ, Allon M (1993) The kidney in sarcoidosis. J Am Soc Nephrol 3: 1555-1562.

7. Berliner AR1, Haas M, Choi MJ (2006) Sarcoidosis: the nephrologist's perspective. Am J Kidney Dis 48: 856-870.

8. Longcope WT, Freiman DG (1952) A study of sarcoidosis; based on a combined investigation of 160 cases including 30 autopsies from The Johns Hopkins Hospital and Massachusetts General Hospital. Medicine (Baltimore) 31:1-132.

9. Branson JH, Park JH (1954) Sarcoidosishepatic involvement: presentation of a case with fatal liver involvement; including autopsy findings and review of the evidence for sarcoid involvement of the liver as found in the literature. Ann Intern Med 40: 111-145

10. Mignon F, Méry JP, Mougenot B, Ronco P, Roland J, et al. (1984) Granulomatous interstitial nephritis. Adv Nephrol Necker Hosp 13: 219-245.

11. O'Riordan E, Willert RP, Reeve R, Kalra PA, O'Donoghue DJ, et al. (2001) Isolated sarcoid granulomatous interstitial nephritis: review of five cases at one center. Clin Nephrol 55: 297-302.

12. Nadasdy T, Sedmak D (2007) Acute and chronic tubulointerstitial nephritis. In Jennette JC, Olson JL, Schwartz MM, Silva FG. Heptinstall's pathology of the kidney (6th edn), Lippincott Williams \& Wilkins, Philadelphia, USA, 1083-1137.

13. Diagnostic standard and guidelines for sarcoidosis (2007) Japanese journal of sarcoidosis and other granulomatous disorders. 27: 89-102 (in Japanese).

14. Bolton WK, Atuk NO, Rametta C, Sturgill BC, Spargo BH (1976) Reversible renal failure from isolated granulomatous renal sarcoidosis. Clin Nephrol 5: 8891.

15. Muther RS, McCarron DA, Bennett WM (1980) Granulomatous sarcoid nephritis: a cause of multiple renal tubular abnormalities. Clin Nephrol 14: $190-$ 197.

16. Williams PF, Thomson D, Anderton JL (1984) Reversible renal failure due to isolated renal sarcoidosis. Nephron 37: 246-249.

17. Hannedouche T, Grateau G, Noël LH, Godin M, Fillastre JP, et al. (1990) Renal granulomatous sarcoidosis: report of six cases. Nephrol Dial Transplant 5: 1824.

18. Okada H, Konishi K, Suzuki H, Mukai M, Sakaguchi H, et al. (1993) Steroidresponsive renal insufficiency due to idiopathic granulomatous tubulointerstitial nephritis. Am J Nephrol 13: 164-166.

19. Utaş C, Doğukan A, Patiroğlu TE, Oymak S, Oymak O (1999) Granulomatous interstitial nephritis in extrapulmonary sarcoidosis. Clin Nephrol 51: 252-254.

20. El-Reshaid KA, Al-Khaldi EH, Madda JP (2000) Granulomatous interstitia nephritis and acute Renal failure due to renal-limited sarcoidosis. Saudi $J$ Kidney Dis Transpl 11: 48-52.

21. Fernández Girón F, Fernández Mora F, Conde-García J, Benítez Sánchez M, Merino Pérez MJ, et al. (2001) Granulomatous interstitial nephritis, hypercalcemia and rapidly progressive kidney failure secondary to sarcoidosis with exclusive renal involvement. Am J Nephrol 21: 514-516.

22. Robson MG, Banerjee D, Hopster D, Cairns HS (2003) Seven cases of granulomatous interstitial nephritis in the absence of extrarenal sarcoid. Nephrol Dial Transplant 18: 280-284.

23. Carmichael P, O'Donnell JP (2003) The protean face of renal sarcoid. J Nephrol 16: 721-727.

24. Miyoshi K, Okura T, Manabe S, Watanabe S, Fukuoka T, et al. (2004) Granulomatous interstitial nephritis due to isolated renal sarcoidosis. Clin Exp Nephrol 8: 279-282.

25. Mitome J, Kawaguchi Y, Arase S, Horino T, Okada H, et al. (2004) A case of renal sarcoidosis: a special reference to calcium metabolism as a diagnostic and the therapeutic implications. Clin Exp Nephrol 8: 375-379.

26. Thumfart J, Müller D, Rudolph B, Zimmering M, Querfeld U, et al. (2005) Isolated sarcoid granulomatous interstitial nephritis responding to infliximab therapy. Am J Kidney Dis 45: 411-414.

27. Moudgil A, Przygodzki RM, Kher KK (2006) Successful steroid-sparing treatment of renal limited sarcoidosis with mycophenolate mofetil. Pediatr Nephrol 21: 281-285

28. Ahmed MM, Mubashir E, Dossabhoy NR (2007) Isolated renal sarcoidosis: a rare presentation of a rare disease treated with infliximab. Clin Rheumatol 26: 1346-1349.

29. Hobbs DJ, Barletta GM, Chung JY, Bunchman TE (2009) Isolated sarcoid granulomatous interstitial nephritis in pediatrics: a case report and review of literature. Clin Nephrol 72: 410-413

30. Ghani AA, Al Waheeb S, Al Homoud E (2011) Isolated sarcoid rena granulomatous tubulointerstitial disease. Saudi J Kidney Dis Transpl 22: 12081210.

31. Unsal A, Basturk T, Koc Y, Sakacı T, Ahbap E, et al. (2013) Renal sarcoidosis with normal serum vitamin D and refractory hypercalcemia. Int Urol Nephrol 45: $1779-1783$

32. Silverstein E, Pertschuk LP, Friedland J (1979) Immunofluorescent localization of angiotensin converting enzyme in epithelioid and giant cells of sarcoidosis granulomas. Proc Natl Acad Sci U S A 76: 6646-6648.

33. Studdy PR, Bird R (1989) Serum angiotensin converting enzyme in sarcoidosis-its value in present clinical practice. Ann Clin Biochem 26: 13-18.

34. Shultz T, Miller WC, Bedrossian CW (1979) Clinical application of measurement of angiotensin-converting enzyme level. JAMA 242: 439-441.

35. Baur X, Fruhmann G, Dahlheim H (1981) Follow-up on angiotensin-converting enzyme in serum of patients with sarcoidosis. Respiration 41: 133-138. 